Reprod. Nutr. Dévelop., 1980, 20 (1 B), 289-294.

\title{
Development of growth hormone receptors in rabbit and lamb liver after hypophysectomy
}

\author{
par A. VEZINHET, B. POSNER *, Barbara PATEL *, J. CHARRIER \\ Station de Physiologie animale, I.N.R.A., \\ E.N.S.A., place Viala, 34060 Montpellier Cedex, France \\ * McGill University, Department of medicine, Montreal, Canada.
}

Summary. The prolactin receptors of rat liver are pituitary-dependent, and previous studies have shown that prolactin itself plays a role in inducing and maintaining their presence. This study tried to determine if hepatic growth hormone (GH) receptors are comparably dependent on the pituitary. Young 47-day and older 116-day old rabbits were either hypophysectomized $(H)$ or sham-operated $(S)$. Hypophysectomy completely arrested the growth of the older rabbits but only reduced it by $50 \mathrm{p} .100$ in the young ones. After 21 days, the specific binding (sb) of ${ }^{125}$ l-labelled human $\mathrm{GH}(\mathrm{hGH})$ to liver membranes was measured in $H$ and $S$ animals. The sb of hGH in $H$ rabbits compared to $S$ animals (older, young) was 14.9 p. 100 in older $\mathrm{H}$ rabbits and 45.5 p. 100 in young $\mathrm{H}$ animals.

Similar studies in lambs showed that the sb of hGH in $\mathrm{H}$ lambs (compared to $S$ animals) was 23.9 p. 100 . When some $\mathrm{H}$ lambs were treated with $1 \mathrm{mg} / \mathrm{kg}$ of oGH or bGH 3 times per week, the sb of hGH was significantly increased to $56.1 \mathrm{p} .100$ of the $\mathrm{S}$ levels. All changes in sb reflected changes in receptor number, as shown by the dose response binding curves.

This study demonstrates that hepatic $\mathrm{GH}$ receptors in both the rabbit and the lamb are pituitary-dependent. The level in rabbits is correlated with the growth rate. Since GH receptor levels were partially restored in $\mathrm{GH}$-treated lambs, it is possible that $\mathrm{GH}$ plays a role in inducing its own receptors.

\section{Introduction.}

Previous studies (Vezinhet, 1968b) have shown that hypophysectomizing the 100day old rabbit arrests growth completely. Before that age, hypophysectomy only reduces growth. Hypophysectomizing the lamb causes a definite decrease of weight gain in both sexes operated on day 25, 50 or 100 after birth (Vezinhet, 1968a). The bovine growth hormone (bGH) treatment used on lambs induces an important decrease in weight gain compared to the hypophysectomized controls (Vezinhet and Dauzier, 1970).

The results presented here are preliminary data obtained in a study to determine if hepatic growth homone receptors are pituitary-dependent. The complete results of this study will be published later. Prolactin and growth hormone receptors have been identified in the liver of different species by Posner (1976), and rat liver prolactin 
receptors have been shown to be pituitary-dependent. In addition, there is now strong evidence indicating that prolactin plays a key role in inducing and maintaining the presence of its own hepatic receptors. It is of great interest to ascertain if the same process is true for the growth hormone.

\section{Material and methods.}

Experimental procedure. - The rabbits were hypophysectomized by the technique of Jacobsohn and Westman (1940), adapted and improved by Vezinhet (1976). Nine 47-day old rabbits from the same litter were used in studying the effect of hypophysectomy on young rabbits; 1 male and 4 females were hypophysectomized, leaving 1 male and 3 females as controls. A second litter of eight 116-day old female rabbits was divided equally into control and hypophysectomized groups. All the rabbits were maintained at a constant postoperative temperature of $20^{\circ} \mathrm{C} \pm 2^{\circ}$ and fed ad libitum. Postoperative care included $300000 \mathrm{IU}$ (IM) of extencilline for up to $2 \mathrm{~kg}$ of body weight and $600000 \mathrm{IU}$ above $2 \mathrm{~kg} ; 7.5 \mathrm{mg} / \mathrm{kg}$ (IM) of hydrocortisone acetate in $10 \mathrm{ml}$ (young group) or $20 \mathrm{ml}$ (older group) of a 20 p. 100 glucose solution was injected subcutaneously. The young group required additional injections of glucose to alleviate a marked hypoglycemia. Twenty to 22 days after hypophysectomy, all the rabbits were killed by exsanguination. Their livers were removed, placed in $0.25 \mathrm{M}$ sucrose solution, divided into segments, sealed in plastic sheets and frozen at $-80^{\circ} \mathrm{C}$.

The sixteen male lambs used were sired by 1 pure Romanoff ram and 16 Merino d'Arles ewes. Five animals were kept as controls, and the remaining 11 were hypophysectomized at the age of 50 days by the trans-sphenoidal approach previously described by Vezinhet (1976).

Postoperative care included $600000 \mathrm{IU}$ of extencilline, $1 \mathrm{~g}$ of didromycine and $7.5 \mathrm{mg}$ of cortisone acetate. In addition, all the hypophysectomized lambs received $15 \mathrm{mg}$ of cortisone acetate given in three IM injections per week. The growth hormone treatment began on postoperative day 14 and ended on day 30 . The 4 hypophysectomized lambs of one group were each given $1 \mathrm{mg}$ of bGH (Byla ; $1.6 \mathrm{IU} / \mathrm{mg}$ ), and each of the 2 lambs in a second group was given the same dose of oGH (made in our laboratory; $1.6 \mathrm{IU} / \mathrm{mg}$ ) 3 times per week, making a total of 6 injections. These animals were killed by exsanguination 3 days after the last injection, or at 33 postoperative days. The livers were removed and stored as described above.

For specific binding measurement, the liver tissue was thawed on ice prior to homogenization. Liver microsomes were prepared as described in a previous publication (Posner, 1976). Studies were performed with 125l-labelled human growth hormone $(h \mathrm{GH})$. The range of specific activity was 129 to $144 \mu \mathrm{Cl} / \mu \mathrm{g}$. Specific binding to individual microsomes was measured as described by Posner (1976).

\section{Results.}

Hypophysectomy of the older 116-day rabbits induced a complete arrest of growth (fig. 1), whereas, although the growth rate in young rabbits 47 days old declined by about 50 p. 100, growth did not completely stop (fig. 2). 
Specific ${ }^{125}$-hGH binding in hypophysectomized animals showed a marked reduction (fig. 3), which was more pronounced in the older than in the young animals

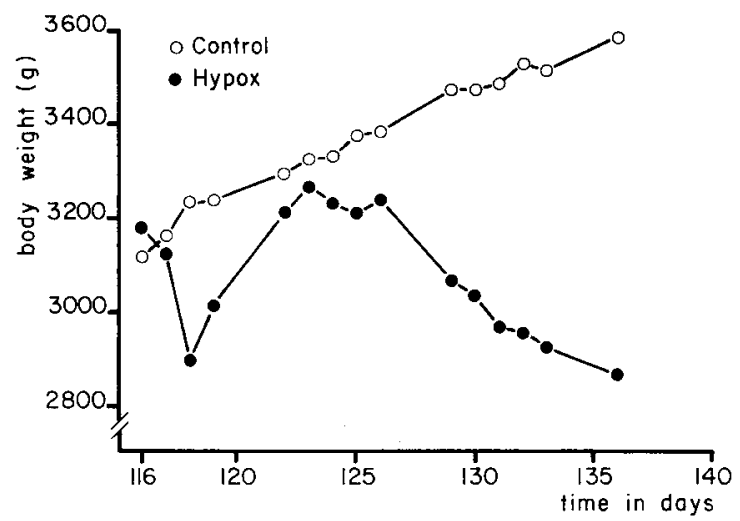

FIG. 1. - Body growth curves of hypox 116 days old rabbits and sham-hypox control animals.

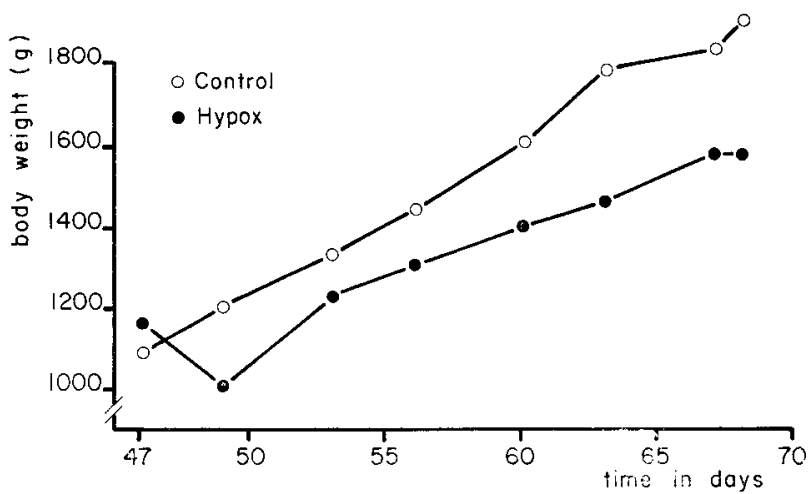

FIG. 2. - Body growth curves of hypox 47 days old rabbits and sham-hypox control animals.

FIG. 3. - Influence of hypophysectomy on the specific binding of ${ }^{1-i}$-labelled hGH in rabbit liver membranes; comparison between 116-day old and 47-day old hypox rabbits. The values are the means and the line above each bar is the SEM for the number of the animals used in each group (see experimental procedure). WIIIA 116 days at hypox: 47 days at hypox : $\mathrm{C}=$ Control ; $\mathrm{H}=$ Hypox

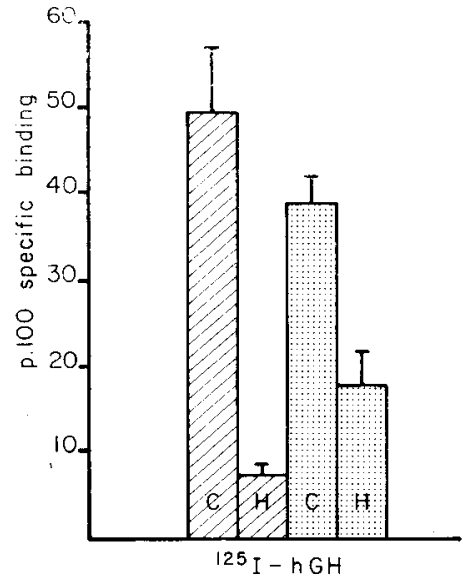


Twenty-one days after surgery, the specific binding of hGH (expressed in percentage of the control sham-operated value assessed as 100 p. 100) was 14.9 p. 100 in hypophysectomized older rabbits and 45.5 p. 100 in the young ones.

Hypophysectomized lambs (50 days) showed a marked reduction in growth (fig. 4). The growth hormone (bGH or oGH) treatment of these animals did not improve the growth rate over that in the untreated hypophysectomized lambs.

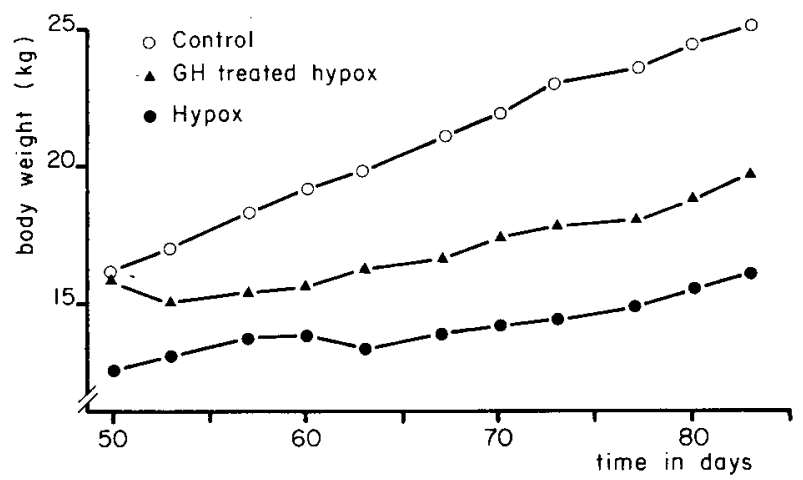

FIG. 4. - Body growth curves of hypox lambs, hypox lambs receiving bGH or oGH treatment (three times $1.6 \mathrm{IU} / \mathrm{kg}$ body weight per week) and sham-operated control animals. All animals were 50 days at surgery.

As seen in figure 5, hypophysectomy caused a marked decrease in specific 125l-hGH binding. Expressed as a percentage at 33 postoperative days, the specific binding measured in hypox compared to sham-operated animals was $23.9 \mathrm{p} .100$. The growth hormone treatment resulted in the retention of a significantly higher level of binding than in the untreated hypox animals. Specific hGH binding increased to 56.1 p. 100 of the sham operated levels.

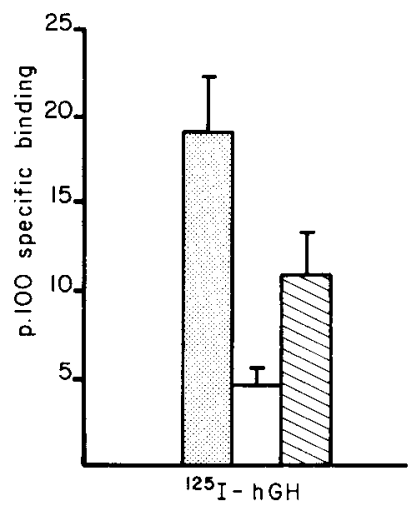

FIG. 5. - Influence of hypophysectomy (with or without $\mathrm{GH}$ treatment) on the specific binding of 1 inl-labelled hGH in lamb liver membranes: comporison of hypox lambs, hypox lambs treated with bGH or oGH (three times $1.61 \cup \mathrm{kg}$ body weight per week) and sham-hypox control lambs. All animals were 50 days at surgery. The values are the means and the line above each bar is the SEM for the number of animals used in each group (see experimental procedure). 1 Control ; $\square$ Siypox ; MIIUbGH, oGH-ireated.

\section{Discussion and conclusion.}

These studies show that hypophysectomy of both young and older rabbits, as well as lambs, resulted in a marked reduction of their hepatic growth hormone binding 
sites which, however, did not disappear completely. Hypophysectomy of the young rabbits (judged as complete by careful postmorfem microscopic examination of the sella turcica) did not induce growth to cease completely. This was previously observed in young rabbits (Vezinhet, 1968b).

These results agree with those of Walker et al. (1950) who failed to obtain any growth arrest in hypophysectomized rats less than 30 days old, and with those of Goussopoulos (1978) who noted a muscular growth arrest in chickens at 15 weeks, while hypophysectomy had been carried out at 7 weeks; however, muscular growth arrest was immediate when hypophysectomy was done after the 15 -week stage. With a more accurate technique using oxytetracycline as an intravital marker, Thorngren et al. (1973) even estimated that longitudinal bone growth in the rat continues until 60 days, if hypophysectomy is performed before that age. Mitchell, Guillemin, Selye (1954) and Knobil and Greep (1959) reported that hypophysectomy of the guinea-pig did not affect its body development at all.

Similarly, Charrier and Vezinhet (1980) have shown that somatomedin A (SmA) bioactivity in hypophysectomized rabbits depends on the age at surgery. In 180-day old operated animals, SmA could not be measured 1 to 2 weeks after surgery, and later on, the sera were inhibitors. On the contrary, in 40-day hypophysectomized growing rabbits, the drop in activity was much less evident and the sera were stimulators. The age of 40 days corresponds to a stage when body weight gain is maximal (Cantier et al., 1969 ; Beaton, 1976). The latter author studying two 50-60-day old rabbits, reported that serum sulphation activity, determined by the porcine assay, declined from 0.36 and $0.48 \mathrm{U} / \mathrm{ml}$ to 0.25 and $0.14 \mathrm{U} / \mathrm{ml}$, respectively, 10 days after hypophysectomy. These results agree with those of Salmon and Daughaday (1957) who noted that hypophysectomy in 21-day old rats decreased serum sulphation activity but did not completely arrest it.

Our preliminary results suggest the pituitary dependence of hepatic growth hormone receptors.

For one thing, the continued (but retarded), growth in the young rabbits after hypophysectomy was accompanied by a less marked drop in growth hormone receptors than in the older animals in which growth stopped.

On the other hand, the pituitary factor which reduces hepatic growth hormone receptors when eliminated, might be the growth hormone itself, as shown by the study on lambs : those which were hypophysectomized and treated with growth hormone showed significantly higher receptor levels than untreated animals. These results agree with those of Vezinhet and Dauzier (1970) who showed that long-term bovine growth hormone treatment increased the weight gain of hypophysectomized lambs. The rate of gain of the treated hypophysectomized lambs closely resembled that of the sham-hypophysectomized control animals. In this study, the lack of improvement in the growth rate, in spite of the increment in receptor number, could be attributed to a too-short hormonal treatment. 
Résumé. Une étude a été entreprise pour savoir si les récepteurs hépatiques à l'hormone de croissance $(\mathrm{GH})$ sont comme ceux de la prolactine (oPRL), sous contrôle hypophysaire.

Des lapins jeunes (45 jours) et plus âgés (115 jours) ont été hypophysectomisés. L'hypophysectomie arrête complètement la croissance des lapins âgés mais ne réduił que de $50 \mathrm{p}$. 100 celle des jeunes. Après 21 jours de survie la liaison spécifique (sb), avec les membranes d'hépatocytes de l'hormone $\mathrm{GH}$ humaine $(\mathrm{h} G \mathrm{H})$, marquée à ${ }^{125}$, a été mesurée chez les hypophysectomisés $(H)$ et des témoins $(T)$. La sb chez $H$ comparé à $T$ est respectivement chez les lapins jeunes et âgés de 45,5 et 14,9 p. $100(\mathrm{hGH})$.

Des études semblables chez l'Agneau ont montré que sb de $\mathrm{H}$ par rapporł à $\mathrm{T}$ était de 23,9 p. $100(\mathrm{hGH})$. Des agneaux $(\mathrm{H})$ traités chroniquement à la bGH ou à la $\mathrm{GH}$ ovine (oGH) ont un sb qui augmente considérablement jusqu'à 56,1 p. 100 de (T). Les variations de sb semblent être imputables à des variations du nombre des récepteurs. Cette étude montre que les récepteurs hépatiques à la GH sont, chez le Lapin et l'Agneau, sous contrôle hypophysaire. La GH pourrait jouer un rôle dans l'induction et le maintien de ses propres récepteurs.

\section{References}

BEATON G. R., 1976. Studies on serum somatomedin activity and cartilage responsiveness in the regulation of growth. Thes. Ph-D, Johannesburg., 280 PP.

CANTIER J., VEZINHET A., ROUVIER R., DAUZIER L., 1969. Allométrie de croissance chez le lapin (Oryctolagus cuniculus). I. - Principaux organes et tissus. Ann. Biol. anim. Bioch. Biophys., 9, 5-39.

CHARRIER J., VEZINHET A., 1980. Somatomedin-A activity in rabbit serum after hypophysectomy. Reprod. Nutr. Dévelop., 20, 93-104.

GOUSSOPOULOS J., 1978. Efude de la croissonce relotive postnofole chez le poulet. Principaux tissus ef organes, muscles et os individuels. Influence de I'hypophysectomie. Th. Dr. Univ. Montpellier. $102 \mathrm{pp}$.

JACOBSOHN D., WESTMAN A., 1940. A parapharyngeal method of hypophysectomy in rabbits. Acta physiol. scand., 1, 71-76.

KNOBIL E., GREEP R. O., 1959. The physiology of growth hormone with particular reference to its action in the rhesus monkey and the "species specificity " problem. Recent Progr. Horm. Res., 15, 1-69.

MITCHELL M. L., GUILLEMIN R., SELYE H., 1954. The effect of somatotrophic hormone on the growth of normal and hypophysectomized guinea pigs Endocrinology, 54, 111-114.

POSNER B. I., 1976. Growth hormone and prolactin receptors : characteristics and regulation, Proceed. Vth int. Congr. Endocrinol., Hamburg, Vol. 2. Excerpta med. int. Congr. Sér. 403. Endocrinology. Ed. H. T. JAMES, 178-185.

SALMON W. D., DAUGHADAY W. H., 1957. A hormonally controlled serum factor which stimulates sulphate incorporation by cartilage in vitro. J. Lab. clin. Med., 49, 825-836.

THORNGREN K. G., HANSSON L. I., MENANDER-SELLMAN K., STENSTROM A., 1973. Effect of hypophysectomy on longitudinal bone growth in the rat. Calc. Tiss. Res., 11, 281-300.

VEZINHET A., 1968a. Effet de l'hypophysectomie sur la croissance pondérale de l'agneau. C. $R$. Acad. Sci. Paris, sér. D. 266, 388-390.

VEZINHET A., 1968b. Effet de l'hypophysectomie sur la croissance pondérale du lapin. C. R. Acad. Sci. Paris, Sér. D, 266, 2348-2351.

VEZINHET A., 1976. Ełude du tissu adipeux chez l'agneau et le lapin après la naissance : développement, lipolyse, lipogenèse. Influence de l'hypophysectomie et de l'hormone de croissance. Th. Dr. Sci., Montpellier, $170 \mathrm{PP}$.

VEZINHET A., DAUZIER L., 1970. Influence de traitements à l'hormone somatotrope bovine sur la croissance pondérale d'agneaux normaux ou hypophysectomisés. Ann. Biol. anim. Bioch. Biophys., 10, 5-13.

WALKER D. G., SIMPSON M. E., ASLING C. N., EVANS H. M., 1950. Growth and differentiation in the rat following hypophysectomy at 6 days of age. Anat. Rec., 106, 539-554. 